8. Gundrie JJ, Pouw RE, Sondermeijer CM, Peters FP, Curvers WL, Rosmolen WD, et al. Stepwise circumferential and focal ablation of Barrett's esophagus with high-grade dysplasia: results of the first prospective series of 11 patients. Endoscopy. 2008;40:359-69.

9. Ganz RA, Overholt BF, Sharma VK, Fleischer DE, Shaheen NJ, Lightdale CJ, et al. Circumferential ablation of Barrett's esophagus that contains high-grade dysplasia: a U.S. multicenter registry. Gastrointest Endosc. 2008;68:35-40.

10. Velanovich V. Endoscopic endoluminal radiofrequency ablation of Barrett's esophagus: initial results and lessons learned. Surg Endosc. 2009;23: 2175-80.

11. Lyday WD, Corbett FS, Kuperman DA, Kalvaria I, Mavrelis PG, Shughoury AB, et al. Radiofrequency ablation of Barrett's esophagus: outcomes of 429 patients from a multicenter community practice registry. Endoscopy. 2010;42:272-8.
12. Eldaif SM, Lin E, Singh KA, Force SD, Miller DL. Radiofrequency ablation of Barrett's esophagus: short-term results. Ann Thorac Surg. 2009;87:405-10.

13. Fleischer DE, Sharma VK. Endoscopic ablation of Barrett's esophagus using the HALO system. Dig Dis. 2008;26:280-4.

14. O'Connell K, Velanovich V. Effects of Nissen fundoplication on endoscopic endoluminal radiofrequency ablation of Barrett's esophagus. Surg Endosc. 2011; 25:830-4.

15. Zehetner J, DeMeester SR, Hagen JA, Ayazi S, Augustin F, Lipham JC, et al. Endoscopic resection and ablation versus esophagectomy for high-grade dysplasia and intramucosal adenocarcinoma. J Thorac Cardiovasc Surg. 2011;141:39-47.

16. Herrero LA, van Vilsteren FGI, Pouw RE, ten Kate FJW, Visser M Seldenrijk CA, et al. Endoscopic radiofrequency ablation combined with endoscopic resection for early neoplasia in Barrett's esophagus longer than $10 \mathrm{~cm}$. Gastrointest Endosc. 2011;73:682-90.

\title{
Radiofrequency ablation for nondysplastic Barrett's esophagus: Should we do it, because we can?
}

\author{
Nirmal Veeramachaneni, MD
}

The treatment of patients with Barrett's esophagus has been a topic of intense investigation for the last several decades. Although it is well recognized that Barrett's esophagus may develop into dysplasia and then progress to invasive esophageal cancer, initial studies comparing fundoplication surgery and the best medical management available demonstrated no difference in either regression of the Barrett's esophagus or diminution of cancer risk. ${ }^{1}$ More modern randomized, controlled trials that investigated laparoscopic fundoplication or long-term proton pump inhibitor use also did not demonstrate any regression of Barrett's esophagus with either strategy ${ }^{2}$ after 5 years of follow-up. In fact, the American Gastroenterological Association does not currently recommend routine surgery (fundoplication) to treat Barrett's esophagus. ${ }^{3}$ Strategies to eradicate Barrett's esophagus by means of radiofrequency ablation in patients with high-grade dysplasia, however, have

\footnotetext{
From the Division of Cardiothoracic Surgery, University of North Carolina-Chapel Hill, Chapel Hill, NC.

Disclosures: Author has nothing to disclose with regard to commercial support.

Received for publication July 31, 2011; accepted for publication Aug 25, 2011; available ahead of print Aug 16, 2011.

Address for reprints: Nirmal Veeramachaneni, MD, Thoracic Surgery, University of North Carolina-Chapel Hill, 3040 Burnett, Womack CB 7065, Chapel Hill, NC

27599 (E-mail: ; nirmalv@med.unc.edu).

J Thorac Cardiovasc Surg 2011;142:1173-4

$0022-5223 / \$ 36.00$

Copyright (c) 2011 by The American Association for Thoracic Surgery

doi:10.1016/j.jtcvs.2011.08.034
}

demonstrated efficacy in preventing the progression to esophageal cancer. ${ }^{4}$

In the accompanying article in this issue of the Journal, Korst and colleagues ${ }^{5}$ have extended the application of radiofrequency ablation technology in a phase 2 trial of patients with Barrett's esophagus without evidence of dysplasia ( $72 \%$ of patients enrolled). This study demonstrated efficacy in eradicating Barrett's esophagus in 78\% of treated patients. Patients with large hiatal hernias were found to be at risk for impaired healing of the esophageal lining after radiofrequency ablation. This study provides valuable information on the intensity of follow-up and treatment necessary to treat Barrett's esophagus with radiofrequency ablation technology. There is considerable variation with respect to the number of radiofrequency ablation treatments needed, with as many as 5 treatments needed for patients with less than $2 \mathrm{~cm}$ Barrett's esophagus and as many as 8 treatments needed for patients with greater than $5 \mathrm{~cm}$ of Barrett's esophagus. Treatments were done at 2-month intervals. Although the study patients have undergone careful endoscopic follow-up, the long-term efficacy of the strategy remains unclear. Korst and colleagues ${ }^{5}$ are unable to provide long-term follow-up data, and the rate of recurrent Barrett's esophagus is unknown. In addition, there is no assessment for potential buried islands of Barrett's esophagus. Furthermore, given the low rate of progression of nondysplastic Barrett's esophagus to cancer, the utility of the intervention, even if successful, is unclear. 
Routine endoscopic screening for Barrett's esophagus in the general population is currently not recommended. ${ }^{3}$ For patients with Barrett's esophagus without dysplasia, followup surveillance endoscopy is only recommended every 3 to 5 years, in recognition of the relatively low risk of progression to more advanced dysplasia. More intense surveillance and possibly surgical resection or ablation is recommended if more advanced dysplasia is discovered.

In light of the ambiguity of the natural history of Barrett's esophagus without dysplasia, radiofrequency ablation should currently only be done in the context of a clinical trial. Although this article by Korst and colleagues ${ }^{5}$ brings up intriguing possibilities, routine radiofrequency ablation for nondysplastic Barrett's esophagus should not be considered the standard of care. Further work allowing risk stratification of subjects at increased likelihood for progression to high-grade dysplasia and cancer will be necessary for better targeting of this intervention in low-risk populations.

\section{References}

1. Spechler SJ, Lee E, Ahnen D, Goyal RK, Hirano I, Ramirez F, et al. Long-term outcome of medical and surgical therapies for gastroesophageal reflux disease: follow-up of a randomized controlled trial. JAMA. 2001;285:2331-8.

2. Galmiche JP, Hatlebakk J, Attwood S, Ell C, Fiocca R, Eklund S, et al. Laparoscopic antireflux surgery vs esomeprazole treatment for chronic GERD: the LOTUS randomized clinical trial. JAMA. 2011;305:1969-77.

3. American Gastroenterological Association, Spechler SJ, Sharma P, Souza RF, Inadomi JM, Shaheen NJ. American Gastroenterological Association medical position statement on the management of Barrett's esophagus. Gastroenterology. 2011;140:1084-91.

4. Shaheen NJ, Sharma P, Overholt BF, Wolfsen HC, Sampliner RE, Wang KK, et al. Radiofrequency ablation in Barrett's esophagus with dysplasia. $N$ Engl J Med. 2009;360:2277-88

5. Korst RJ, Santana-Joseph S, Rutledge JR, Antler A, Bethala V, Delillo A, et al. Effect of hiatal hernia size and columnar segment length on the success of radiofrequency ablation for Barrett's esophagus: a single-center, phase II clinical trial. $J$ Thorac Cardiovasc Surg. 2011;142:1168-73. 